\title{
Chloroplast and Total Genomic Diversity in the Endemic Costa Rican Tree Lonchocarpus costaricensis (J. D. Smith) Pittier (Papilionaceae).
}

\author{
By C. Navarro ${ }^{1, *}$,, S. Cavers ${ }^{2)}$, N. ColpaerT ${ }^{3)}$, G. Hernandez ${ }^{1}$, P. Breyne ${ }^{4)}$ and A. J. Lowe ${ }^{2,5)}$
}

(Received 26 $6^{\text {th }}$ July 2005)

\begin{abstract}
In Mesoamerica, tropical dry forest is a highly threatened habitat, and species endemic to this environment are under extreme pressure. The tree species, Lonchocarpus costaricensis is endemic to the dry northwest of Costa Rica and southwest Nicaragua. It is a locally important species but, as land has been cleared for agriculture, populations have experienced considerable reduction and fragmentation. To assess current levels and distribution of genetic diversity in the species, a combination of chloroplast-specific (cpDNA) and whole genome DNA markers (amplified fragment length polymorphism, AFLP) were used to fingerprint 121 individual trees in 6 populations. Two cpDNA haplotypes were identified, distributed among populations such that populations at the extremes of the distribution showed lowest diversity. A large number (487) of AFLP markers were obtained and indicated that diversity levels were highest in the two coastal populations (Cobano, Matapalo, $H=0.23,0.28$ respectively). Population differentiation was low overall, $F_{S T}=0.12$, although Matapalo was strongly differentiated from all other populations $\left(F_{S T}=\right.$ 0.16-0.22), apart from Cobano $\left(F_{S T}=0.11\right)$. Spatial genetic structure was present in both datasets at different scales: cpDNA was structured at a range-wide distribution scale, whilst AFLP data revealed genetic neighbourhoods on a population scale. In general, the habitat degradation of recent times appears not to have yet impacted diversity levels in mature populations. However, although no data on seed or saplings were collected, it seems likely that reproductive mechanisms in the species will have been affected by land clearance. It is recommended that efforts should be made to conserve the extant genetic resource base and further research undertaken to investigate diversity levels in the progeny generation.
\end{abstract}

Key words: AFLPs, chloroplast DNA, genetic differentiation, genetic diversity, Lonchocarpus costaricensis, spatial genetic structuring.

1) Centro Agrónomico Tropical de Investigación y Enseñanza, Cartago, Turrialba 7170, Costa Rica.

2) Centre for Ecology and Hydrology, Bush Estate, Penicuik, Midlothian EH26 0QB, Scotland, UK.

$\left.{ }^{3}\right)$ Institute for Plant Biotechnology for Developing Countries, Department of Molecular Genetics, Gent University, K.L. Ledeganckstraat 35, B-9000 Gent, Belgium.

4) Institute for Forestry and Game Management, Research Station of the Flemish Community, Gaverstraat 4, 9500 Geraardsbergen - Belgium.

5) School of Integrative Biology, John Hines Building, The University of Queensland, Brisbane, QLD 4072, Australia.

*) Carlos Navarro, Centro Agrónomico Tropical de Investigación y Enseñanza, Cartago, Turrialba 7170, Costa Rica. Email: cnavarro@catie.ac.cr

\section{Introduction}

Mesoamerica is home to more than 5000 endemic plants, around $1.7 \%$ of the world's plant species (MYERS et al., 2000). Such high levels of endemism combined with a rapid rate of habitat loss have identified it as one of the world's biodiversity hotspots, where action to conserve biodiversity can have maximum impact. Within this region, tropical dry forest is arguably the most threatened of habitats (JANZEN, 1988; KwON and MoRDEN, 2002; CESPEDES et al., 2003) and widespread clearance for agriculture has left only approx. $1 \%$ of the original forest cover (SANCHEZ-AzofEIFA et al., 2001; CESPEDES et al., 2003). From a genetic point of view, the population size reduction and fragmentation that tree species in this habitat are experiencing are highly likely to adversely affect long-term survival, erode diversity and degrade ecological and evolutionary processes (HAMRICK and GODT, 1996). Such concerns are particularly pertinent for regions with high endemism, given the growing evidence for climate change (IPCC (Intergovernmental Panel on Climate Change) 2001), as species with restricted niches are likely to be disproportionately affected (Bawa and Dayanandan, 1998; MCLaughrin et al., 2002; HAMRICK, 2004).

For rare and endemic species, survival in the short term will probably be determined by demographic and ecological factors (LANDE, 1988; Schemske et al., 1994), with the greatest threat likely to be anthropogenic. However, survival in the long term depends, at least partly, on the maintenance of genetic variability and of gene flow mechanisms (HAMrICK and GoDT, 1996). In a landscape of forest fragments, the potential to maintain connectivity between remnant populations will dictate the ability to maintain genetic diversity (HAMRICK, 2004). Furthermore, an understanding of the level and distribution of genetic diversity can allow evaluation of the effects of habitat fragmentation and inform management strategies for remnant populations. For example, where ex-situ conservation or restoration are considered, empirical data can direct collection of a representative sample of variation, allow matching of provenances to recipient populations and assess the impacts of seed collection on remnant populations (HAMRICK and GoDT, 1996).

Recently, comparative analyses drawing on studies using allozymes (HAMrICK and GoDT, 1989) and DNA markers (NYBOM and BARTISH, 2000) have explored how different life history characteristics affect levels and distribution of genetic diversity. In these syntheses, longlived, outcrossing species were found to maintain most variation within populations. In allozyme studies (HAMRICK and GODT, 1989) endemic, narrowly distributed 
species were found to maintain lower levels of genetic diversity relative to widespread species, although little difference in partitioning of variation was observed. In contrast, NYBOM and BARTISH (2000) failed to detect a relationship between within-population diversity and geographic range. Logically, there seems no reason why local endemics, if outcrossing and able to maintain genetic connectivity across large population sizes, should necessarily show reduced levels of genetic variation (BAWA and AsHTON, 1991). Indeed, once phylogenetic relationships are taken into account through comparisons between rare and widespread congeners (AYRES and RYAN, 1999; GITZENDANNER and Soltis, 2000), whilst average levels of diversity are lower in rare species, they show as wide a range of levels of diversity and of population differentiation as widely distributed species. In other words, generalisations are fraught with difficulty and each species should be considered a novel, unique entity (HAMrick, 1983; GiTZENDANNER and Soltis, 2000). Collection of empirical data on a case by case basis is therefore vital.

The tropical tree species Lonchocarpus costaricensis (Papilionaceae), known locally as Chaperno, is endemic to the lowland deciduous forests on the Pacific side of Costa Rica and Nicaragua (HoLDRIDGE et al., 1997), although it may be found in moist forest up to $1000 \mathrm{~m}$ above sea level (HoLDRIDGE et al., 1997). Despite being of considerable utility due to its production of a natural nematicide (many Lonchocarpus species produce insecticidal or pharmacologically-useful compounds; BALANDRIN et al., 1985) the species has to date been little studied. The dry forests of northwestern Costa Rica and Pacific Nicaragua, where L. costaricensis is found, have been severely impacted by human activities and in general, little undisturbed vegetation remains.

Lonchocarpus costaricensis is a medium to large-sized deciduous tree that grows to $20 \mathrm{~m}$ in height and may live to over 100 years (JANZEN et al., 1990). It is reportedly pollinated by Centris aethyctera and C. fuscata anthophorid bees, (JANZEN et al., 1990; JANZEN, 1991). Adult trees normally produce hundreds to tens of thousands of flat indehiscent wind-dispersed fruits, at intervals of 2 years and sometimes longer (JANZEN, 1982). Fruits are tough legumes, with a smooth texture; most are single-seeded, but a few have 2 or 3 seeds. The seeds are often eaten by the larvae of several species of hostspecific bruchid Ctenocolum beetles, but are rejected by vertebrate seed predators (JANZEN et al., 1990).

In Costa Rica L. costaricensis is commonly associated with pioneer species (such as Cecropia sp., Cordia alliodora and Erythrina sp., C Navarro pers comm), although it is encountered in all stages of forest succession. Individuals are usually found scattered throughout the forest, rather than in patches (JANZEN, 1982; JANZEN et al., 1990), preferring slopes and eroded or rocky soils. Despite the heavy impact of farming for cattle, $L$. costaricensis has survived well through abundant seed production and fast and aggressive regeneration ( $\mathrm{O}$. MÉNDEZ, pers comm). Indeed, for some farmers, this can cause problems as when cut it will coppice and, if weeding is not intense, pure stands can form. Lonchocarpus costaricensis is not a valuable timber species but is used locally to construct fences and for fuelwood.

The aim of this study is to use molecular markers to assess levels of genetic diversity and population differentiation in $L$. costaricensis, and evaluate the extent of connectivity between populations through gene flow. To assess the relative contributions of pollen versus seed flow to genetic connectivity between populations, a combined approach of universal chloroplast markers (assumed to be maternally inherited and therefore seedspecific) and total genomic (AFLP) markers are used. The data are compared with those derived for other endemic tree species and the likely implications for long term persistence of the species are considered.

\section{Methods}

Samples were collected from a total of $121 \mathrm{~L}$. costaricensis individuals from 6 populations throughout northwest Costa Rica (Guanacaste lowlands and the Nicoya peninsula coast, Figure 1, Table 1). A population was defined as a group of trees, all at least $100 \mathrm{~m}$ apart but within a coherent geographic area, such that they are in potential reproductive contact. After the collection made for this study Lonchocarpus costaricensis is considered Vulnerable according to the IUCN (2001) based on the following criteria: A. Reduction in population size based on any of the following: 1 . An observed, population size reduction of $50 \%$ over the last 10 years, where the causes of the reduction are: clearly reversible and understood and ceased; B. Geographic range in the form of either B2 (area of occupancy) a. Severely fragmented or known to exist at no more than 10 locations.

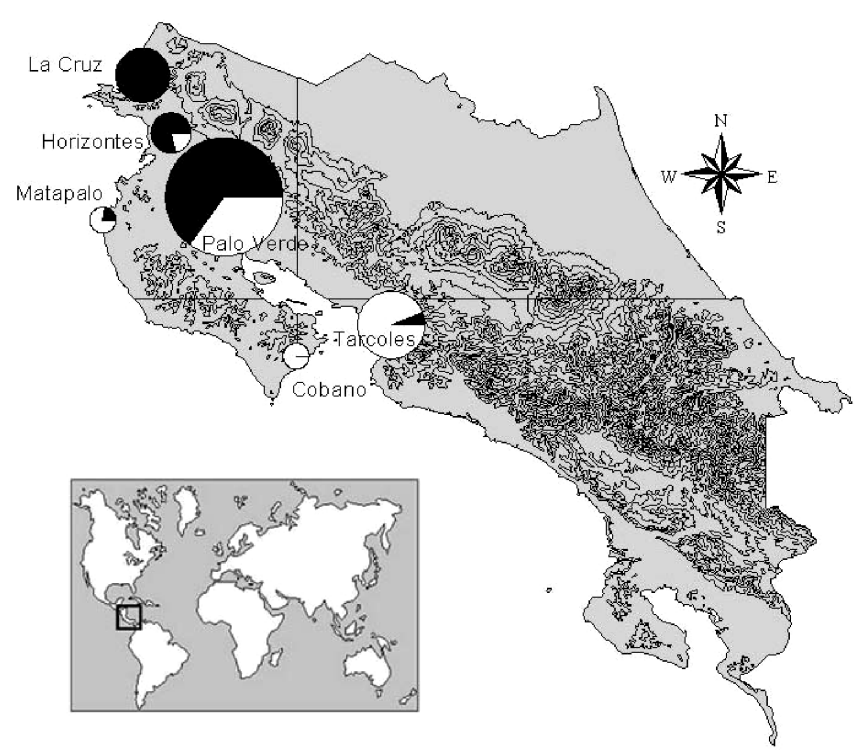

Figure 1. - Relief map of Costa Rica with names and locations of Lonchocarpus costaricensis populations sampled. Inset shows location of Costa Rica on a global scale. The distribution of the two cpDNA haplotypes identified is shown. Haplotype A - with insertion: black, Haplotype B - without insertion: white. Charts are proportional to number of individuals characterised, population Palo Verde represents 20 individuals. Populations Cobano and Matapalo lie at south and north ends of the Nicoya peninsula respectively: the land to the east of the peninsula we describe here as the Guanacaste lowlands. 
Table 1. - Details of populations of L. costaricensis collected for the study. Abbreviations are Lat.- latitude, Long. - longitude, Alt. - altitude, DBH - Mean diameter at breast height, Ht. - Mean height.

\begin{tabular}{lcccccc}
\hline Population & $\begin{array}{c}\text { Lat. } \\
(\mathrm{N})\end{array}$ & $\begin{array}{c}\text { Long. } \\
(\mathrm{W})\end{array}$ & $\begin{array}{c}\text { Alt. } \\
(\mathrm{m})\end{array}$ & $\begin{array}{c}\text { DBH } \\
(\mathrm{cm})\end{array}$ & $\begin{array}{c}\text { Ht. } \\
(\mathrm{m})\end{array}$ & Characteristics \\
\hline La Cruz & $10^{\circ} 73^{\prime}$ & $85^{\circ} 59^{\prime}$ & 200 & 16.25 & 11.65 & $L c$ abundant, young secondary forest / grassland \\
Palo Verde & $10^{\circ} 20^{\prime}$ & $83^{\circ} 73^{\prime}$ & 240 & 14.55 & 11.65 & Regenerating forest, young, area now protected \\
Matapalo & $9^{\circ} 92^{\prime}$ & $84^{\circ} 25^{\prime}$ & 900 & 16.92 & 10.57 & $L c$ highly abundant, mature secondary forest \\
Cobano & $85^{\circ} 00^{\prime}$ & $10^{\circ} 22^{\prime}$ & 100 & 12.87 & 10.65 & $L c$ abundant, young secondary forest / grassland \\
Horizontes & $85^{\circ} 35^{\prime}$ & $10^{\circ} 34^{\prime}$ & 50 & 15.40 & 8.90 & Regenerating following complete cut / burning \\
Tarcoles & $8^{\circ} 60^{\prime}$ & $82^{\circ} 90^{\prime}$ & 40 & 16.25 & 11.20 & Forest remnants, some old $L c$ near rivers / farms \\
\hline
\end{tabular}

Individuals were sampled by collection of leaf tissue, which was dried on silica gel. The spatial position of each tree was recorded during collection using a hand held GPS. Genomic DNA was extracted from leaves using a modified CTAB protocol as described in GILLIES et al. (1997).

Chloroplast DNA (cpDNA) was screened for variation using PCR-RFLP in the conserved regions identified by (TABERLET et al., 1991; DEMESURE et al., 1995; DUMOLINLAPEGUE et al., 1997; HAMILTON, 1999). The PCR protocol was as described in Demesure et al. (1995). PCR fragments were digested using combinations of several restriction enzymes (4-base: HinfI, MspI, AluI, HaeIII; 6-base: EcoRV, PstI, HindIII) and RFLP fingerprints were visualised on $8 \%$ non-denaturing acrylamide gel in a Hoefer SE600 electrophoresis unit (300V) using Tris borate EDTA buffer (1X). Once polymorphic markers had been detected, the whole collection was characterised for cpDNA haplotype, using these loci. The data set was analysed for within-population $\left(H_{\mathrm{Sc}}\right)$ and total $\left(H_{\mathrm{Tc}}\right)$ diversity and for the level of population subdivision $\left(\mathrm{G}_{\mathrm{ST}} ;\right.$ (Pons and PeTiT, 1995)) using the program HAPLONST (Pons and PETIT, 1995).

The AFLP protocol was as described in (Vos et al., 1995), using the selective primer combinations Eco + $\mathrm{GT} / M s e+\mathrm{ACAT}, E c o+\mathrm{CG} / M s e+\mathrm{ACAC}, E c o+\mathrm{CG} / M s e$ $+\mathrm{ACCT}, E c o+\mathrm{AG} / M s e+\mathrm{ACAC}, E c o+\mathrm{GA} / M s e+\mathrm{ACAC}$, $E c o+\mathrm{GA} / \mathrm{Mse}+\mathrm{ACAA}$. AFLP fingerprints were visualised on a manual sequencing rig using 33P $\gamma$-ATP, (Amersham). Reactions were denatured for 5 min.s at $95^{\circ} \mathrm{C}$ prior to loading, then $1 \mu \mathrm{l}$ of reaction was loaded onto a 5\% denaturing polyacrylamide gel (Roth). Gels were manually scored for presence/absence of bands and a binary matrix was prepared. Levels of genetic diversity within populations $\left(H_{W}\right)$ and for the data set as a whole $\left(H_{T}\right)$ and level of population subdivision $\left(F_{S T}\right)$ were determined using the program AFLP-SURV (VEKEMANS et al., 2002), employing the Bayesian method with nonuniform prior distribution (ZHIVOTOVSKY, 1999) to estimate allele frequencies from dominant data. Based on a matrix of pairwise $F_{S T}$ values and 1000 resampled datasets (generated using AFLP-SURV) to compute bootstrap support values, a consensus Neighbour-Joining tree was produced using NEIGHBOR and CONSENSE in the PHYLIP package (FELSENSTEIN, 1993). The tree was visualised using TREEVIEW 1.6.6 (Page 1996).

The ratio of pollen to seed flow was estimated according to (ENNOS, 1994), using the equation:
Pollen flow $/$ Seed flow $=$

$\left[\left(1 / F_{S T b}-1\right)-2\left(1 / F_{S T m}-1\right)\right] /\left(1 / F_{S T m}-1\right)$

where $F_{S T b}$ is the population differentiation calculated for AFLP loci and $F_{S T m}$ is the population differentiation calculated for (assumed maternally inherited) cpDNA loci (i.e. $G_{S T}$ ).

Spatial genetic structure was analysed by autocorrelation of spatial distance and genetic distance based on both chloroplast and AFLP datasets (using the software package Spatial Genetic Software, SGS, (DEGEN et al., 2001)). Genetic distance between trees was estimated using Tanimoto's distance for AFLP data and Gregorius' distance for cpDNA data. Mean pairwise genetic distance (observed) was determined for eight distance classes of $20 \mathrm{~km}$; upper and lower $95 \%$ confidence intervals (upper $95 \%$ CI and lower 95\% CI) were determined for each distance class based on 1000 random resamplings of genotypes among the existing tree coordinates. Where the observed value was less than the lower $95 \%$ CI, there was significant positive spatial genetic structure, with individuals more genetically similar than expected at random: where the observed value exceeded the upper $95 \%$ CI, there was significant negative spatial genetic structure, with individuals more genetically distant than expected at random. Oscillation from significant lower to upper $95 \%$ CIs indicated the size of genetic neighbourhood for a particular data set. A plot of mean pairwise genetic distance against distance class (a distogram) was prepared for easy visualisation of the spatial scale of genetic structure within a population.

\section{Results}

A single clearly polymorphic cpDNA locus was identified ( $p s b$ C-trnS, DEMESURE et al., 1995, digested with Hinf I). This $30 \mathrm{bp}$ length mutation allowed characterisation of two haplotypes: Haplotype A - insertion present, Haplotype B - insertion absent. The mean within population diversity $\left(H_{W}\right)$ was $0.23(\mathrm{SE} 0.09)$ and total diversity level $\left(H_{W}\right)$ was 0.55 (SE 0.03).

The level of population subdivision $\left(\mathrm{G}_{\mathrm{ST}}\right)$ was 0.59 ( $\mathrm{SE}$ 0.18). Two populations (La Cruz and Cobano) were fixed for single, different halotypes (Figure 1). The other populations contained both haplotypes. In general, moving from north to south through the region sampled, haplotype A was found in fixation (La Cruz), then intermediate populations (Horizontes, Palo Verde, Matapalo) show both haplotypes, with decreasing frequency of haplotype A until in the south haplotype B is in fixation (Cobano) or predominant (Tarcoles). 
Table 2. - Within-population $\left(H_{W}\right)$ and total $\left(H_{T}\right)$ genetic diversity for six populations of $L$. costaricensis from Costa Rica, with allele frequencies estimated using a Bayesian method with non-uniform prior distribution of allele frequencies, implemented in AFLP-SURV. The data set consisted of 487 loci from six AFLP primer combinations.

\begin{tabular}{|c|c|c|c|c|c|c|}
\hline \multirow[t]{2}{*}{ Population } & \multicolumn{2}{|c|}{ Population size } & \multirow{2}{*}{$\begin{array}{c}\text { No. of } \\
\text { polymorphic loci } \\
(5 \% \text { level })\end{array}$} & \multirow{2}{*}{$\begin{array}{c}\% \text { of } \\
\text { polymorphic } \\
\text { loci }(5 \% \\
\text { level })\end{array}$} & \multirow[t]{2}{*}{$H$} & \multirow{2}{*}{$\begin{array}{c}H, \\
\text { Std. Error }\end{array}$} \\
\hline & AFLP & cpDNA & & & & \\
\hline La Cruz & 20 & 20 & 297 & 61.0 & 0.21 & 0.01 \\
\hline Palo Verde & 20 & 20 & 291 & 59.8 & 0.19 & 0.01 \\
\hline Matapalo & 20 & 20 & 395 & 81.1 & 0.28 & 0.01 \\
\hline Cobano & 20 & 20 & 315 & 64.7 & 0.23 & 0.01 \\
\hline Horizontes & 21 & 20 & 295 & 60.6 & 0.19 & 0.01 \\
\hline \multirow[t]{3}{*}{ Tarcoles } & 20 & 20 & 300 & 61.7 & 0.20 & 0.01 \\
\hline & & & & Mean $H_{W}$ & 0.22 & 0.01 \\
\hline & & & & Total $H_{T}$ & 0.24 & 0.01 \\
\hline
\end{tabular}

AFLP analysis obtained 487 fragments, of which $98.6 \%$ were polymorphic (Table 2). Genetic diversity levels for individual populations ranged from $H_{W}=$ $0.19-0.28$ and total diversity was $H_{T}=0.24$. The level of population differentiation was relatively low overall $\left(F_{S T}=0.12\right)$, however Matapalo was strongly differentiated from all other populations $\left(F_{S T}=0.16-0.22\right)$ apart from Cobano $\left(F_{S T}=0.11\right)$. This divergence was evident in cluster analysis (Neighbour-joining tree, Figure 2) and

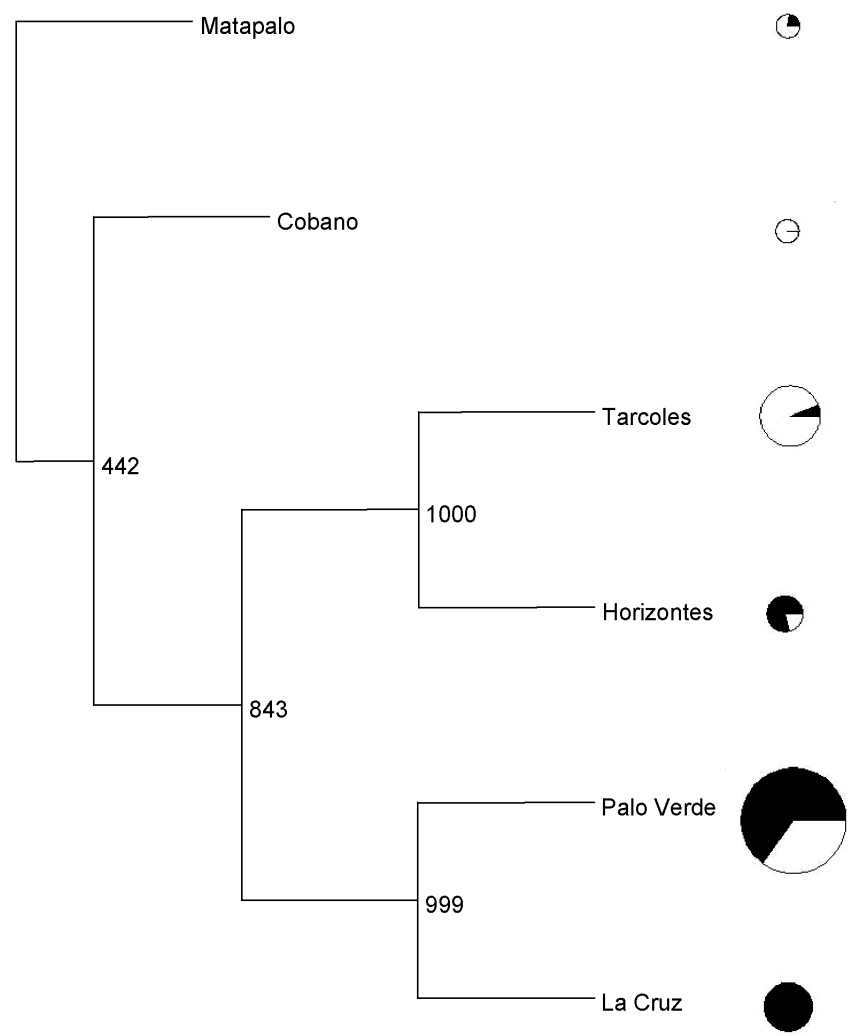

Figure 2. - Neighbour Joining tree constructed using a pairwise $\mathrm{F}_{\mathrm{ST}}$ matrix (bootstrapped using 1000 resampled datasets). The matrix was based on AFLP variation at 487 loci in six Lonchocarpus costaricensis populations. Figures alongside branches indicate the number of times out of 1000 that branch ocurred. Pie charts show number of two cpDNA haplotypes found in each population; charts proportional to number of individuals characterised, population Palo Verde represents 20 individuals. furthermore grouping of populations La Cruz and Palo Verde, and Horizontes and Tarcoles were strongly supported by bootstrapping. Levels of diversity in Matapalo $\left(H_{W}=0.28\right)$ and Cobano $\left(H_{W}=0.23\right)$ populations were
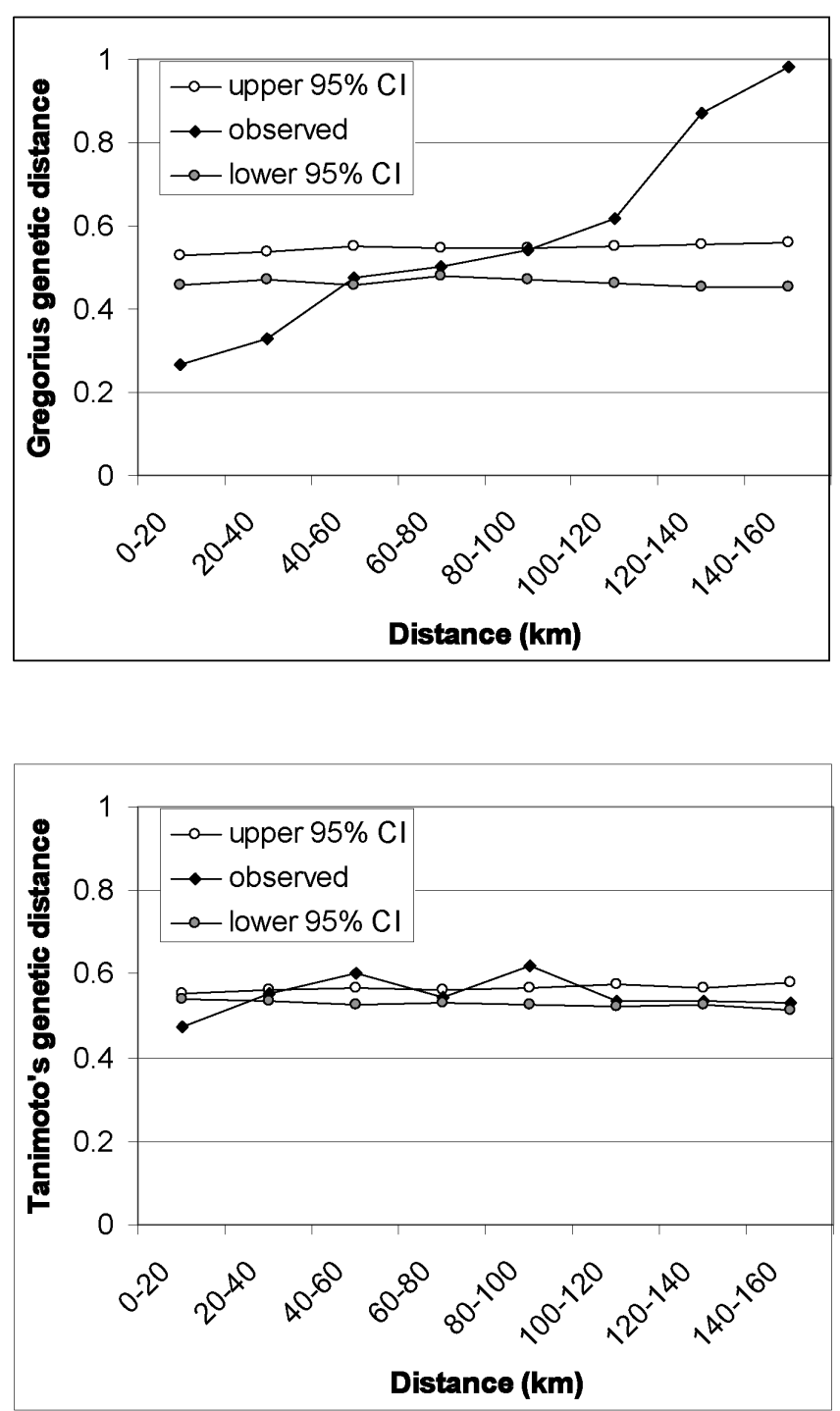

Figure 3. - Distograms for spatial autocorrelation analysis of mean pairwise genetic distance for datasets comprising a), top, two cpDNA haplotypes and b), bottom, 487 AFLP loci. 
higher than those found in the other four populations $\left(H_{W}=0.19-0.21\right)$. Comparing levels of population differentiation for AFLP and cpDNA loci, interpopulation pollen flow was calculated to be 8.55 times greater than seed flow.

Significant positive spatial autocorrelation (i.e. individuals within a distance class more genetically similar than expected at random) was detected for both AFLP and cpDNA data sets (Figure 3). However the scale of the genetic neighbourhood and the magnitude of correlation varied greatly between the marker types. For cpDNA very strong and significant spatial autocorrelation was identified (observed genetic distance between 0.20 and 0.95 ) over a large genetic neighbourhood scale (up to the largest distance class of $150 \mathrm{~km}$ ). For the AFLP data a much lower, though still significant spatial autocorrelation was identified (0.46 to 0.62$)$ over a more limited spatial scale $(50 \mathrm{~km})$. The difference between these two measures is most likely a reflection of the genetic differentiation contribution of pollen-mediated gene flow.

\section{Discussion}

Levels of diversity in rare or endemic species are generally considered to be reduced (HAMRICK and GODT, 1989), particularly as small population size is likely to threaten loss of diversity through stochastic processes alone. However, whilst comparative analyses of allozyme datasets detected reduced diversity in endemic species, analogous studies of rare and widespread congeners have shown that the range of diversity levels in rare species is comparable to that in widespread species (GitzendANNER and Soltis, 2000). In other words, endemism as a characteristic is not a good predictor of diversity level.

In L. costaricensis, levels of whole-genome (AFLP) diversity are relatively high $(0.19-0.28)$, with little differentiation between populations $\left(F_{S T}=0.12\right)$. The species appears to be maintaining high levels of withinpopulation variation and effectively ensuring connectivity between populations. The pattern of genetic diversity partitioning is within the range observed for many other outcrossing tropical tree species, with the large majority contained within-population: e.g. Swietenia macrophylla $\left(H_{T}=0.36, F_{S T}=0.12\right.$, RAPDs, GILLIES et al., 1999), Ilex paraguarensis $\left(H_{T}=0.16, F_{S T}=0.15\right.$, RAPDs, GAUER and CAVAlli-Molina, 2000), Calycophyllum spruceanum $\left(H_{T}=0.28, F_{S T}=0.09\right.$, AFLPs, RUSSELl et al., 1999), Vochysia ferruginea $\left(H_{T}=0.26, F_{S T}=0.15\right.$, AFLPs, CAVERS et al., 2005). The pattern of diversity estimated by chloroplast markers also indicates high within-population diversity $\left(\mathrm{H}_{\mathrm{W}}=0.23\right)$ and, though the level of population differentiation is much higher $\left(\mathrm{G}_{\mathrm{ST}}=0.59\right)$, this is expected for a slow-evolving, maternally-inherited, non-recombining locus. The pattern of divergence in cpDNA haplotype frequency between the North and South of the sampled range does suggest some limitation in gene flow via seed over the long term, probably indicating that the large, flat seeds tend to be locally dispersed despite apparent adaptations for wind-dissemination.

The pollen flow/seed flow ratio obtained for $L$. costaricensis (8.55) is low in comparison with other species (e.g. pollen/seed flow $=196$ for $Q$. robur/petraea, 24-68 for Pinus sp., calculated in ENNos, 1994, 2.5 for Argania spinosa, (EL MousAdIK and PETIT, 1996) assuming that the inheritance of the chloroplast is maternal, as in most angiosperms (BIRKY, 1995). Given the strong geographic structure observed for the chloroplast data, the low pollen/seed flow ratio may suggest some limitation in pollen dispersal, perhaps due to some aspect of pollinator behaviour. Certainly, the highest values of pollen/seed flow tend to be observed in species with wind- rather than insect-dispersed pollen.

The spatial scales of spatial genetic structure for cpDNA and AFLP data are likely to reflect differences in colonization dynamics and patterns of contemporary, predominantly pollen-mediated, gene flow, respectively. The pattern of cpDNA variation may be consistent with either admixture of previously isolated northern and southern source populations or with an ancient original population somewhere near the centre of the distribution, with fixation of different haplotypes occurring in populations near the extremes of the distribution through lineage sorting during dispersal. Spatial analysis indicated that individuals at short distance separation were more likely to share haplotypes whilst those at long distance were more likely to have different haplotypes, reflecting the differential fixation observed in the populations at the edges of the distribution. The area around La Cruz and nearby Santa Elena is geologically the oldest part of Costa Rica (COATES and ABANDO, 1996), and would be a likely location for an ancient population. However, the formation of the Nicoya peninsula may also have provided opportunities for dispersal and isolation that could have produced multiple source populations

The pattern of AFLP variation is likely to result from more contemporary influences. The size of genetic neighbourhood is only at the scale of single populations. Thus whilst individual populations appear to represent

Table 3. - Pairwise Fst between populations for six populations of $L$. costaricensis from Costa Rica. The data set consisted of 487 loci from six AFLP primer combinations.

\begin{tabular}{lllllll}
\hline & La Cruz & Palo Verde & Matapalo & Cobano & Horizontes & Tarcoles \\
\hline La Cruz & 0.00 & & & & & \\
Palo Verde & 0.05 & 0.00 & & & & \\
Matapalo & 0.16 & 0.22 & 0.00 & & & \\
Cobano & 0.05 & 0.09 & 0.11 & 0.00 & & \\
Horizontes & 0.10 & 0.12 & 0.20 & 0.06 & 0.00 & \\
Tarcoles & 0.10 & 0.13 & 0.20 & 0.05 & 0.03 & 0.00 \\
\hline
\end{tabular}


intact genetic entities, larger spatial genetic patterns are difficult to identify. However, $F_{S T}$ values (Table 3 ) indicate strong differentiation of Matapalo from the populations of the Guanacaste lowlands $\left(F_{S T}=0.16-0.22\right)$, with otherwise generally low pairwise differentiation, $\left(F_{S T}=0.05-0.13\right)$. Such a pattern indicates that populations have, in general, been experiencing substantial gene flow throughout the distribution and the small divergence observed is likely to be due only to isolation by distance. Despite strong bootstrap support for clusters of populations within the distribution (Figure 2), none of these populations are highly differentiated (Table 3), and the principal observation therefore remains the isolation of Matapalo.

The differentiation of Matapalo may reflect interaction of pollen-mediated gene flow dynamics and this landscape. The most influential landscape feature in the range of $L$. costaricensis is the mountains of the Nicoya Peninsula (rising to $>1000 \mathrm{~m}$ ), which begin about $10 \mathrm{~km}$ north of Matapalo and proceed in a southeasterly direction ending almost at the tip of the Peninsula, near Cobano. It is notable therefore that Matapalo also maintains the highest level of within-population diversity, and similar in magnitude to Cobano (and from which it is least differentiated). Potentially, long term gene flow may have occurred principally on an axis parallel to the Nicoya mountains, linking Cobano and Matapalo via the Nicoya peninsula and maintaining isolation between Matapalo and the populations of the Guanacaste lowlands. Such a process would also explain the lack of differentiation between Cobano and the other populations.

However, there are additional factors that potentially may be confounding this interpretation. Characteristics of the populations themselves and the way in which they were sampled must also be taken into account. The entire distribution has been impacted heavily by human activity and the populations sampled have contrasting recent histories (Table 1). In particular, those populations on sites that have been completely cleared for cattle ranching (Horizontes, Palo Verde) and have subsequently regenerated show lowest diversity levels. Furthermore, populations with higher diversity, Matapalo and Cobano, are located in more forested regions, with potentially more mature and abundant $L$. costaricensis. Therefore, it seems possible that the contrasting diversity levels between populations may be an artefact of recent human impact, with populations that have experienced most substantial disturbance showing correspondingly reduced diversity. However, the collection was designed only to sample diversity throughout the distribution and did not seek specific causes: a more systematic approach to selection of populations will be required to conclusively establish the link between disturbance history and diversity.

In general, L. costaricensis maintains high levels of diversity, despite relatively small population size, and effective levels of gene flow between populations. Given the dramatic anthropogenic impact experienced by the species in recent years, it appears that certain of the species' characteristics act to maintain diversity in the face of considerable disturbance. For example, mature trees can be cut down once a year without causing death. This aggressive resprouting may ensure that eradication of individual trees is quite difficult, and populations may persist despite clearance. As a consequence, the widespread deforestation of the last fifty years, converting forests to grasslands for cattle farming may not yet have impacted the genetic resources of $L$. costaricensis. In addition, abundant production of seeds ensures that opportunities for regeneration are taken.

In fact, as for most of the region, large scale deforestation and habitat fragmentation are relatively recent phenomena, with the majority of the clearance having taken place during the last fifty years or so. Diversity levels therefore most probably reflect the pre-clearance situation, when populations were more continuous, a hypothesis supported by the low levels of population differentiation observed. The reduction in population size that has undoubtedly taken place has not yet had time to impact diversity levels through random loss of alleles due to genetic drift with the increased population differentiation that would accompany it. However, it seems highly likely that reproductive mechanisms in the species will be affected and fragmentation effects will become apparent in the progeny generation (LowE et al., 2005). The directionality of this impact is difficult to predict however, as it depends on the effect of fragmentation on pollinators and has been observed to both increase levels of gene flow (WHITE et al., 1999; Dick, 2001) and reduce it (HALL et al., 1996). To verify the impact of fragmentation on the species will require analysis of seed and sapling populations - ideally undertaken using co-dominant markers to allow exploration of the mating system (Lowe et al., 2005).

For L. costaricensis the most pressing concerns, as for most of the endemic species of Mesoamerica, are anthropogenic. The dramatic loss of habitat and consequent demographic and ecological impacts will have outcomes that have yet to become apparent. Nevertheless, the species is resilient and regenerates strongly and should be well placed to recover given the right protection. What remains unclear, is how the demographic impacts of the past fifty years will affect the population in the future. Gene flow mechanisms in the species appear to be effective, but the estimates derived here most probably reflect a pre-clearance situation and the operation of those mechanisms in the contemporary landscape needs to be explored. A diverse genetic base still persists in the remnant populations of $L$. costaricensis but it will be important for the long-term survival of the species that the connectivity between these populations is maintained, or future environmental changes are likely to force a rapid loss of diversity and increase the likelihood of extinction of this potentially useful species.

\section{Acknowledgements}

The work reported in this paper was conducted as part of the European Union funded project "Assessment of levels and dynamics of intra-specific genetic diversity of tropical trees" (contract \# ERBIC18CT970149 http:// www.nbu.ac.uk/geneo) which was coordinated by A. LowE. Funding is gratefully acknowledged from the EU and 
NERC. The AFLP analysis was carried out at IPBO, University of Gent, Belgium. The hospitality and assistance of the staff there is gratefully acknowledged. The authors wish to thank MARVIN HERNANDEZ and LIONEL $\mathrm{H}$ for assistance in obtaining samples, and JULIA WILSON and KATHERINE WALKER (CEH) for constructive contributions to the manuscript.

\section{References}

AYres, D. R. and F. J. RYAN (1999): Genetic diversity and structure of the narrow endemic Wyethia reticulata and its congener $W$. bolanderi (Asteraceae) using RAPD and allozyme techniques. American Journal of Botany 86: $344-353$.

BAlandrin, M. F., J. A. Klocke, E. S. Wurtele and W. H. Bollinger (1985): Natural plant chemicals: sources of industrial and medicinal materials. Science 228: 1154-1160.

BAWA, K. and S. DAYANANDAN (1998): Global climate change and tropical forest genetic resources. Climatic change 39: 473-485.

BAwA, K. S. and P. S. Ashton (1991): Conservation of rare trees in tropical rain forests: a genetic perspective., pp. in Genetics and conservation of rare plants., edited by D. A. FAlK and K. E. Holsinger, Oxford University Press., New York.

BIRKY, C. W. (1995): Uniparental Inheritance of Mitochondrial and Chloroplast Genes - Mechanisms and Evolution. Proceedings of the National Academy of Sciences of the United States of America 92: 11331-11338.

Cavers, S., C. Navarro, P. Hopkins, R. A. Ennos and A. J. LOWE (2005): Regional and population-scale influences on genetic diversity partitioning within Costa Rican populations of the pioneer tree Vochysia ferruginea Mart. Silvae Genetica.

Cespedes, M., M. V. Gutierrez, N. M. Holbrook and O. J. RochA (2003): Restoration of genetic diversity in the dry forest tree Swietenia macrophylla (Meliaceae) after pasture abandonment in Costa Rica. Molecular Ecology 12: 3201-3212.

Coates, A. G. and J. A. Obando (1996): The Geologic Evolution of the Central American Isthmus, pp. 21-56 in Evolution and Environment in Tropical America edited by Jackson, B. C., A. F. Budd and A. G. Coates. The University of Chicago Press, Chicago.

Degen, B., R. J. Petit and A. Kremer (2001): SGS - Spatial Genetic Software: A computer program for analysis of spatial genetic and phenotypic structures of individuals and populations. Journal of Heredity 92: 447-448.

Demesure, B., N. Sodzi and R. J. Petit (1995): A set of universal primers for amplification of polymorphic noncoding regions of mitochondrial and chloroplast DNA in plants. Molecular Ecology 4: 129-131.

Dick, C. W. (2001): Genetic rescue of remnant tropical trees by an alien pollinator. Proceedings of the Royal Society of London B 268: 2391-2396.

Dumolin-Lapegue, S., M.-H. Pemonge and R. J. Petit (1997): An enlarged set of consensus primers for the study of organelle DNA in plants. Molecular Ecology 6: 393-397.

El Mousadik, A. and R. J. Petit (1996): Chloroplast phylogeography of the argan tree of Morocco. Molecular Ecology 5: 547-555.

ENNos, R. A. (1994): Estimating the relative rates of pollen and seed migration among plant populations. Heredity 72: 250-259.
Felsenstein, J. (1993): PHYLIP: Phylogeny Inference Package. University of Washington, Seattle, Washington.

Gauer, L. and S. CAVAlli-Molina (2000): Genetic variation in natural populations of mate (Ilex paraguarensis A. St.-Hil., Aquifoliaceae) using RAPD markers. Heredity 84: 647-656.

Gillies, A. C. M., J. P. Cornelius, A. C. Newton, C. NAVArRo, M. Hernandez and J. Wilson (1997): Genetic variation in Costa Rican populations of the tropical timber species Cedrela odorata L., assessed using RAPDs. Molecular Ecology 6: 1133-1145.

Gillies, A. C. M., C. Navarro, A. J. Lowe, A. C. Newton, M. Hernandez, J. Wilson and J. P. Cornelius (1999): Genetic diversity in mesoamerican populations of mahogany (Swietenia macrophylla), assessed using RAPDs. Heredity 83: 722-732.

GitzendanneR, M. A. and P. S. Soltis (2000): Patterns of genetic variation in rare and widespread plant congeners. American Journal of Botany 87(6): 783-792.

HALL, P., S. WALKER and K. BAWA (1996): Effect of forest fragmentation on genetic diversity and mating system in a tropical tree, Pithecellobium elegans. Conservation Biology 10: 757-768.

HAMILTON, M. B. (1999): Four primer pairs for the amplification of chloroplast intergenic regions with intraspecific variation. Molecular Ecology 8: 521-522.

HAMRICK, J. L. (1983): The distribution of genetic variation within and among natural plant populations, pp. 335-348 in Genetics and Conservation, edited by C. M. Schonewald-Cox, S. M. Chambers, B. MacBryde and W. L. Thomas, Benjamin/Cummings, Menlo Park, CA.

HAMRICK, J. L. (2004): Response of forest trees to global environmental changes. Forest Ecology and Management 197: 323-335.

HAMRICK, J. L. and M. J. W. GoDT (1989): Allozyme diversity in plant species., pp. 43-63 in Plant population genetics, breeding and genetic resources., edited by A. H. D. Brown, M. T. ClegG, A. L. Kahler and B. S. WeIR, Sinauer Associates Inc., Sunderland, MA.

HAMRICK, J. L. and M. J. W. GODT (1996): Conservation genetics of endemic plant species., pp. in Conservation Genetics: case studies from nature., edited by J. C. Avise and J. L. HAMrick, Chapman \& Hall, New York.

Holdridge, L. R., L. Poveda and Q. Jimenez (1997): Arboles de Costa Rica, Vol. 1, $2^{\text {nd }}$ Edition. Centro Cientifico Tropical, San Jose, Costa Rica.

IUCN (2001): IUCN Red List Categories and Criteria: Version 3.1. IUCN Species Survival Commission. IUCN, Gland, Switzerland and Cambridge, UK. ii + 30 pp.

IPCC (Intergovernmental Panel on Climate Change) (2001): Impacts, adaptation and vulnerability to climate change: 2001, third assessment report of the IPCC, Cambridge, UK, University Press.

JANZEN, D. H. (1982): Weight of dry seeds in 1-3-seeded fruits of Lonchocarpus costaricensis (Leguminosae), a Costa Rican wind-dispersed tree. Brenesia 19/20: $363-368$.

JANZEN, D. H. (1988): Tropical dry forests, the most endangered major tropical ecosystem, pp. 130-137 in Biodiversity, edited by E. O. WILSON, National Academy Press, Washington, DC.

JANZEN, D. H. (1991): How to save tropical biodiversity. American Entomologist 37: 159-171.

Janzen, D. H., L. E. Fellows and P. G. Waterman (1990): What protects Lonchocarpus (Leguminosae) seeds in a Costa Rican dry forest? Biotropica 22: 272-285. 
Kwon, J. A. and C. W. Morden (2002): Population genetic structure of two rare tree species (Colubrina oppositifolia and Alphitonia ponderosa, Rhamnaceae) from Hawaiian dry and mesic forests using random amplified polymorphic DNA markers. Molecular Ecology 11: 991-1001.

LANDE, R. (1988): Genetics and demography in biological conservation. Science 24: 1455-1460.

Lowe, A. J., S. A. HARRIS, P. AshTON (2004): Ecological Genetics: Design, Analysis and Application. Blackwells, Oxford. 326 pp.

Mclaughlin, J. F., J. J. Hellmann, C. L. Boggs and P. R. EHRLich (2002): Climate change hastens population extinctions. Proceedings of the National Academy of Sciences of the United States of America 99: 6070-6074.

Myers, N., R. A. MittermeieR, C. G. MitTermeier, G. A. B. DA FonsecA and J. Kent (2000): Biodiversity hotspots for conservation priorities. Nature 403: 853-858.

NyBom, H. and I. V. BARTiSH (2000): Effects of life history traits and sampling strategies on genetic diversity estimates obtained with RAPD markers. Perspectives in Plant Ecology, Evolution and Systematics 3: 93-114.

PAGE, R. D. M. (1996): TREEVIEW: An application to display phylogenetic trees on personal computers. Computer Applications in the Biosciences 12: 357-358.

Pons, O. and R. J. PetiT (1995): Estimation, variance and optimal sampling of gene diversity I. Haploid locus. Theoretical and Applied Genetics 90: 462-470.

Russell, J. R., J. C. Weber, A. Воотh, W. Powell, C. Sotelo-Montes and I. K. Dawson (1999): Genetic variation of Calycophyllum spruceanum in the Peruvian Amazon Basin, revealed by amplified fragment length polymorphism (AFLP) analysis. Molecular Ecology 8: 199-204.

Sanchez-Azofeifa, G. A., R. C. Harriss and D. L. Skole (2001): Deforestation in Costa Rica: a quantitative analysis using remote sensing imagery. Biotropica 33: 378-384.

Schemske, D. W., B. C. Husband, M. H. Ruckelshaus, C. Goodwillie, I. M. PARker and J. G. Bishop (1994): Evaluating approaches to the conservation of rare and endangered plants. Ecology 75: 584-606.

TABerlet, P., L. Gielly, G. Pautou and J. Bouvet (1991): Universal primers for amplification of three non-coding regions of chloroplast DNA. Plant Molecular Biology 17: 1105-1109.

Vekemans, X., T. Beauwens, M. Lemaire and I. RoldanRUIZ (2002): Data from amplified fragment length polymorphism (AFLP) markers show indication of size homoplasy and of a relationship between degree of homoplasy and fragment size. Molecular Ecology 11: 139-151.

Vos, P., R. Hogers, M. Bleeker, M. ReiJans, T. van DE Lee, M. Hornes, A. Frijters, J. Pot, J. Peleman, M. KUIPER and M. ZABEAU (1995): AFLP: a new technique for DNA fingerprinting. Nucleic Acids Research 23: $4407-4414$

White, G. M., D. H. Boshier and W. Powell (1999): Genetic variation within a fragmented population of Swietenia humilis Zucc. Molecular Ecology 8: 1899-1909.

Zhivotovsky, L. A. (1999): Estimating population structure in diploids with multilocus dominant DNA markers. Molecular Ecology 8: 907-913.

\footnotetext{
Herausgeberin: Bundesforschungsanstalt für Forst- und Holzwirtschaft: Schriftleitung: Institut für Forstgenetik und Forstpflanzenzüchtung, Siekerlandstrasse 2, D-22927 Grosshansdorf — Verlag: J. D. Sauerländer's Verlag, Finkenhofstrasse 21, D-60322 Frankfurt a. M. Anzeigenverwaltung: J. D. Sauerländer's Verlag, Frankfurt am Main. Satz: Satz- und Grafikstudio König, Marburg — Druck: ADN Offsetdruck, Battenberg — Printed in Germany.
} 